\title{
II. Popular Faith
}

The scope of Linnæus' anthropological Dietetic, as already pointed out, was very wide. It includes not only the ways of human living but also a great field of behaviour such as customs and beliefs, for example maypoles, bonfires, curing-wells or the spending of holidays with their charms and omens. To a certain degree Linnæus notes down such matters for amusement, or as anecdotes when illustrating his more serious efforts of presenting the natural manners of simple people. Narrated folklore is almost totally absent here. Black arts and demonic witchcraft were soon out of date in the science of Linnæus' time.

The traits of provincial beliefs and ways of life in remote districts of Sweden in the eighteenth century are certainly of interest to the folkloretopography of our day. However, they are still more characteristic of Linnæus' own personal interests and hence should be considered here from this point of view. Linnæus himself had all the equipment of a good ethnographer and also took an interest in comparing his findings with similar conditions in several provinces of Sweden and even in foreign countries. His mode of rendering such matters in the Swedish language can hardly be surpassed. It is therefore a pity to render them in another tongue.

In his dietetic Linnæus treats superstitions, charms, spells, omens and divination under the heading of animi pathemata, a headline word of ancient date, perhaps best rendered with emotive attitudes of mind. Linnæus makes a very noteworthy distinction between magia and superstitio. From the term magic he excludes false and unlikely representations, such as "the prediction of things to come, changing oneself into other shapes, making oneself invisible, being able to fly through the air ('riding to Blåkulla'), being able to walk dry-shod on the water, giving life to soulless things, being able to call up the spirits of the dead, shades, dead people, demons, to subjugate ghosts, to procure oneself an honorary position, to find hidden treasures, always having money at hand ('pecuniam reducem semper habere'), to be always invulnerable to weapons ('to withstand'), not to be hurt by fire and 
water, to put a spell on somebody's mind in order to attach his feelings to something, to inflict illnesses or a state of stupor (sopire), to mumble words, transference (injectio), pictures."1

According to Linnæus magicians have never maintained such things. They belong in the repertoire of superstitious people and old women.

\section{O caecas hominum mentes, o pectora caeca ${ }^{2}$ \\ Plebis deliria. Aniles fabula.}

Linnæus hereby differentiates between magic and all forms of what is known as witchcraft and sorcery. At the same time he negatively defines what he means by superstition. It is however obvious, that such definitions must partly overlap. Evidently this is the case when he heads ghosts and "idolatry" separately or couples sympathies with magic, which we are obliged to keep together. A modern anthropologist would, without further ado, separate the elements of belief and performance from one another, especially in connection with faith in nature's spiritual beings. ${ }^{3}$

Linnæus' first known literary work, his Örtabok, is a herbalistic notebook which contains information on plants grown for medicinal and domestic purposes and their attributes and uses. The contents of this notebook, which was written by Linnæus at the age of eighteen, has hardly any scientific value, but it does show how Linnæus came to choose a scientific career and how this was determined by his own interests and his knowledge of the botany and medicine which he had acquired from his teacher, Johan Rothman. Sometimes Linnæus made notes concerning his surroundings, but at that time he appears to have lacked a more genuine interest in what the people in the countryside practised in they way of household remedies. Occasionally he did try them, but certainly more in jest than in earnest. However, all such subjects could not have been missed by him. Some leanings towards the old science of the occult are noticeable in the drawings of

1. $L N$-MSS; transl. from the Latin text.

2 LN-MSS; Linnæus quotes from memory Lucretius, De rerum natura II, 14: O miseras hominum mentes, o pectora caeca!

${ }^{3}$ K. Rob. V. Wikman, in: The Supernatural Owners of Nature (Stockholm Studies in Comparative Religion I) ed. by Åke Hultkrantz, Stockholm I96I. 
trees and the explanations attached to them. ${ }^{1}$ His library in his early days also contained a good deal concerning such matters. His studies in medicine had perhaps also some connection with these literary interests. Boerhaave once said: "Credulity is hurtful, so is incredulity: the business therefore of a wise man is to try all things, to hold fast what is approved, never to assign limits to the power of God, nor assign bounds to nature." Without any doubt such views became lodestars for Linnæus in future days.

Anyhow it is very remarkable how early Linnæus paid attention to the popular beliefs of his native surroundings. During his journeys in the Swedish countryside he did not neglect the medical plants, considering that Nature had once and for all given the plants the power to cure. In many cases the differences between empirical and fictitious folk-traditions are nowadays as difficult to define as they were in Linnæus' time.

When in I728 Linnæus went to Upsala, he probably took with him a manuscript on folk beliefs, entitled De reliquiis Paganismi et Papismi in Smolandia. The original has been lost, but no less than three copies are preserved. One of them was obviously made by a friend and fellow student, Carl Fredrik Mennander, who became a Professor and Bishop of A Abo, and then Archbishop of Sweden. The other two copies date from the late I720s and were made by two other students at Upsala, Daniel Torpadius and Johan Johansson Törner. ${ }^{2}$ Another of Linnæus' early friends, Johan Browallius, later Professor and Bishop of Åbo, may have owned a copy (it could possibly have been the original). The handwriting can be traced to the late 1600 s or early I700s. Some statements, probably by Linnæus himself, have been added in the copy by C. F. Mennander. They occur once more in the unpublished section of Lachesis naturalis. It looks as if the original had already disappeared when Linnæus travelled to the islands of Öland and Gotland in $174 \mathrm{I}$ and visited his home county on the journey. Nevertheless Linnæus appears to have had folk beliefs and medicine in mind all the time during his long journey to Lappland in $\mathbf{I} 732$. Observations

1 See Örtabok, figs. III-IV, with ref. to J. G. Müller, Deliciæ hortenses, Stuttgart I684, pars prima, pp. 230 sq.; listed as no. I68, I69 in Caroli Nic. fil. Linnæi Bibliotheca Medica, p. 25.

2 F. F. Törners Samling af widskeppelser, ed. by K. Rob. V. Wikman, Uppsala I946. 
of such matters were in keeping with his aims and the planning of his journey. His aims are evident from his notes concerning Diæta naturalis I733. With the exception of the scientific results from his Lappland journey which to a certain extent were laid down in his famous Flor a lapponica 1737 , the notes from the journey and the dietetic remained unpublished. Only some years ago when Diæta naturalis was published it became possible to comprehend the close connection between Linnæus' two early works. The young traveller's notes concerning religion and magic show his great interest not only in Lapp shaman-drums and medicines but also in the superstitions of the Finnish and Swedish inhabitants of these northern provinces of the realm. During the journey to Holland ${ }^{7} 735^{-1} 73^{8}$ Linnæus adds some general comparisons between Lapps, Siberians and Indians ending up with the remark that "The Doctrine of God is amazingly variable". About the Lapps it is said that they worship thunder, evil spirits and deceased persons. "When they fall ill they say that deceased relations are longing for them; the dead are then offered images, which are buried." 1 A comment on these notes must be omitted here, so much more as Professor Åke Hultkrantz has recently treated this subject very competently. ${ }^{2}$

Linnæus' wide interests obviously became stimulated in I74I when he renewed his connections with his native county. Apart from folk-botany and folk-medicine the purely folkloristic notes from his later journeys in different parts of Sweden are sparsely represented. Suddenly, however, popular beliefs burst into bloom in his descriptions as he approached the neighbourhood where he had spent his childhood and schooldays. Recollections and stories had almost the same effect on him as the flowers of his youth. He felt proud of the monument which was left by his ancestors in the form of stories, traditions and opinions. But this does not mean that he believed in the stories propagated by the people. ${ }^{3}$

This general attitude of Linnæus to superstition, animism and magic pervades all his literary works. Superstitions are in themselves plebis deliria.

$1 D N$, pp. I 92 sq.

2 Cf. Ake Hultkrantz, The Healing Methods of the Lapps, Papers on FolkMedicine at an Inter-Nordic Symposium, Stockholm 8-10 May 1961, pp. 325-35I (Arv vol. 18-19, 1962-1963).

${ }^{3}$ Carl Linnæi öländska och gothländska resa, pp. 307 sq., 320. 
All Linnæus says about spirits and ghosts is that the question of their existence is difficult to answer. "Natural scientists hotly deny it, and why not when they are not of a corporeal nature. All knowledge of them defies positive observations. Dutchmen, Lapps and other peoples know hardly anything about them. Ordinary people, people from Smalland, think that they see spirits and ghosts in the woods at night. Most people's panic-stricken fear is a child of the imagination. To be afraid of the dark is an illness, a habit which is implanted in children so that they dare not venture out into the dark and to stop them crying at home." 1 Consequently Linnæus tries as far as possible, to explain such phenomena in a natural way. In contrast to the conceptions mentioned here we do find natural magic.

The collection of superstitions from the journey in $\mathrm{I} 74 \mathrm{I}$ deals mostly with the traditional customs of the country people. They have been quoted and copied very frequently. The original annotations which are preserved in the records of the journey in the Linnean Society in London differ in certain respects from the diary edited and published in $1745 .^{2}$ The rough draughts show that most notes ought to be dated to the 14 th and 15 th of August I74I. In the original diary for the 15 th of August $174 \mathrm{I}$ we read: "We came back to the Smålandic beliefs which are rather comprehensive." The words hint that earlier in the day such matters had been under discussion with his teacher and friend Johan Rothman. Perhaps they had also been discussed in some larger circle. There is much to show that these notes were based on hearsay from the parental surroundings of Stenbrohult a few days before. Most of the notes deal with rustic festivals and beliefs. Four years later when Linnæus arranged the manuscript for publication he left out notes which, presumably, might have been offensive to a wider public. For some unknown reason the notes were redated to the ${ }_{5}$ th of August, and in one case to the I3th of August I741.

There can be no doubt that the large majority of Linnæus' records, published and unpublished, concerning folk-beliefs originate from Småland. Notes on superstition in his descriptions of the later journeys in other Swedish counties are comparatively few. Notes of this type from his journey

\footnotetext{
${ }^{1}$ LN-MSS (Spectra).

2 'The records from the journey have now been edited by K. Rob. V. Wikman. $S L S A$, XLVII, r964, pp. r6 sqq.
} 
in Västergötland in 1746 are more concerned with folk-medicine and folkbotany. In the spirit of the times Linnæus remarks that Natural history "banishes superstition and forms a basis for all Private Economies and Manufactures on which the well-being of the Kingdom depends". ${ }^{1}$ Although on these later journeys he does not neglect popular customs and similar things, he omits curiosities which do not directly belong to any of Nature's "three provinces". ${ }^{2}$

The Lachesis papers, however, contain a large number of notes about popular superstitions which have been added later. According to some early statements in the anonymous manuscript De reliquiis, mentioned above, it is likely that Linnæus compiled a whole collection of superstitions of older or newer date for his lectures. The part of the Lachesis manuscript which has the title Superstitiones covers 4 close-written pages in folio, comprising altogether c. IIo items. ${ }^{3}$ With the addition of a number of statements about folk-beliefs, which Linnæus inserted in other parts of Lachesis and Nemesis as well as in his printed papers, one can venture to say that his notes form a very considerable collection. Surely, this was the "pretty argument" he himself had in mind when he spoke about such collections.

Notes concerning household cures, very often rendered in medical terms, are scattered in many places. In direct connection with the Smanlandic superstitions he reports on a couple of such practices. Under the title Kloka ('Wise women') we find the strange story of a woman, Ingeborg from Mjärhult." ${ }^{4}$ The story relates that she could describe the illnesses of her patients simply by handling clothes which had been worn by them. She thought that everybody has a double which follows him, and like a reversed reflection in calm water, uti Narcissi umbra, follows him as antipode in a position downwards. If the double should injure an underground spirit, a vätte, älva or $r a \hat{a}$, the person fell ill. The illness was cured by pouring out milk or something similar at a certain time into a northbound stream, on a cairn (Swedish rös), a tree, or in a churchyard (as far as one can see, the place

1 Carl Linnæi Wästgötaresa, printed in 1747, pp. 24I sq.

2 Op. cit., p. 2 ro.

${ }^{3} L N$-MSS fols. r9-2o (to be printed in SLSA). Cf. Öländska och gothländska resa, pp. $28 \mathrm{sq}, 308-3 \mathrm{II}$.

4 LN-MSS; cf. op. cit., pp. $3^{\mathrm{I} 2-3^{\mathrm{I}} 4 .}$ 
where the illness was supposed to come from). In this last respect the practice differs little from other cures of similar kinds. The strange conception of the human double which Ingeborg is said to have entertained, is amazing and has caused a good deal of discussion among folklorists and researchers in religious history. ${ }^{1}$ This story has no parallel in Swedish folklore and could almost be regarded, if not as apocryphal, at any rate as a piece of peasant philosophy. Another wise woman, whom Linnæus met during his journey in Västergötland in 1746 , maintained that "the earth had turned round so that the seasons had changed". 2

Up to the days of Linnæus the structure of popular thought was still highly homogeneous in the central provinces of Sweden. The traditions were a common heritage and the superstitions were practised more or less among all classes of the population. This is clearly shown by the extensive collection of superstitions compiled by Johan Törner, D.D. (I712-1790), a schoolmaster at the Linköping Grammar School in Central Sweden. As a physician Linnæus was a zealous combatant against the widely spread quackery. Especially he was a sworn enemy of curing per expectationem which the adherents of G. E. Stahl recommended. A sick person, Linnæus repeatedly says, is like a ship which needs a competent pilot. "In a calm wind" even "an ignoramus" can pilot a ship. It is, however, inexcusable "to place all one's possessions in such unsafe hands". ${ }^{3}$

It is, however, surprising to find that Linnæus was not impervious when it came to bear on the mind. On the contrary he was eager to test whatever looked like being an explanation of popular beliefs. For this reason his ideas concerning magic acquire importance not only for the understanding of his science but also of his own private thoughts. If he could not clarify the difference between magic and superstition, this was because the explanation of sympathetic magic and superstition must be sought in a common source, viz., the sense of the unknown.

1 G. O. Hyltén-Cavallius, Wärend och wirdarne, I, Stockholm I864, p. 355; Erland Ehnmark in SLSA XXVII, I944, pp. 83 sq.

${ }^{2}$ Wästgötaresa, pp. I00-I02 concerning Sven i Bragnum (cf. the note pp. XXVIIIXXX and corrections and literature quoted by Natanael Beckman in the reprint, Upsala 1928).

3 Ibidem. 
In Lachesis Linnæus has put together a collection of statements, his own and others, under the title manes (hamn). These concern auditive and visionary hallucinations, death omens and such things. He opens up with the words: "I deny the rest, whatever they might be, I do not know." 1 "The rest" probably refers to his notes on ghosts (spectra), which are to be found on the opposite page. When Linnæus is questioned as to the existence of doubles it is obvious that his faith is nearly undoubted. We also meet with this firm belief in Nemesis divina from which the following notes are presented in their original form. ${ }^{2}$ Preceding the Latin text Linnæus writes the following sentence: "According to what many people say (multorum ore), banging is heard from the walls before someone dies." In another place the word manes is defined by the Swedish words hamn or färd. ${ }^{3}$

Vidi I727 Lundini in altissimo, ubi nulla scala, pulsabat 3. extra parietem cameræ mex; hora 3 matutina, expergefactus miror; redit iterum 3 ictus; terrefactus et tertia vice 3 ictus duros pulsat; moritur, tum sana, post aliquot hebdomas, mater Stobæi in proxima camera. ${ }^{4}$

Pater retulit se vidisse vespera, dum carbones adhuc ignitæ illuminabant cameram, introvisse quendam, linteo obvolutum, sedisse juxta focum, abivisse. altero (die) mane dum ancillæ æconomica curant, quærunt num pater exiverat mane in linteo, negat. credit se moriturum; altero die accedit saltator phtisicus, permanet ibi per aliquot hebdomades, moritur. ${ }^{5}$

$1 L N$-MSS, fol. $16^{\mathrm{v}}$.

${ }^{2} N D$-MS $5{ }^{1-53}$. The more strict Latin version in $L N$ is rendered here and in the following.

${ }^{3} L N$-MSS. Under the heading Idolatria (fol. I $o^{r}$ ) is said: The double "is seen before somebody dies, walking in his shirt, banging the wall three times, twice or thrice and three".

${ }^{4} L N$-MSS, fol. $16^{\nabla}$. The date should be 1728 , when Linnæus lived with Prof. Kilian Stobæus in Lund. More details in $N D$, p. 66. (MS ${ }_{5} \mathrm{I}$ ).

${ }_{5}$ Much abridged in ND, p. 57 (MS 53). In the paternal house of Linnaeus "French dancing master" Soberant was dead by 1724 . 
1742. accedens ad Socerum ægrum, ea nocte super me ambulatur, dum in lecto quiesco cum uxore; ambo audivimus; interrogamus quis ibi fuerit postero die, nullus dicitur, et socra clavem apud se habuit. 28 à 29 nocte novembris jacet ager in camera, uxor mea adsidet, non ea nocte mortem expectans patris; intrat cameram ubi affinis vigilans ambulat plena terroris; quærit uxor num pulsabat parietem, altera negat, sed se vidisse per fenestram linteum descendisse, inde terrefactam esse, introeunt ambo, reperiunt socrum meum in agone. ${ }^{1}$

Linnæus relates how he had the same type of experience in 1744 regarding the death of his infant daughter, Sara Magdalena, and also in other connections in later years. ${ }^{2}$ Experiences of this type appear to have followed Linnæus throughout his life, and his disposition in this regard seems to have been a part of his own mental structure. One of Linnæus' students in later years tells that one day he followed his teacher up to his room and: "When we had arrived at his museum he looked at the table and chair where he usually sat when studying and said clearly in a high voice: 'Aha! Is it you sitting there Carl? Sit in peace, I will not disturb you.' I ventured to ask: Sir, whom are you addressing? I sometimes think that I am sitting there (he pointed to the chair) working, he replied." 3 However, whichever way one wishes to interpret such personal documents, they seem to reveal a particular constitutional trait in Linnæus' make-up. At this junction between faith and nonbelief personal and popular conjectures unite in him: quid hoc? an fabula? an aliquid quod sensus nostri non observant?

Surprisingly enough spectra (ghosts) and incubi (nightmares) also appear in this connection. ${ }^{4}$ To comprehend this, we must bear in mind that the clue to Linnæus' presentation is animi pathemata. He talks about spectra, the existence of which is difficult to decide. ${ }^{5}$ Imagination, he says, gives rise to "panic-stricken fear and turns terror of darkness into an illness which impresses itself upon a child through habit and hinders it from venturing

${ }^{1} L N$-MSS, ibidem; also in $N D$, p. 66 (MS 53), where there is a note that two women had heard coffins being nailed, in $L N$ referred to in passing as vulgaria fata.

${ }^{2} L N-M S S$, ibidem and $N D$, MS 52 sq.

${ }^{3}$ In his footnote to the text $N D$, p. 64 Fries refers to this very remarkable story by Dean C. G. Rollin, published by himself in a paper, Stockholm 1857 .

${ }^{4} L N-M S S$, fol. $16^{r, v}$ and $10^{r}$.

${ }^{5}$ In the original: Spectra an dentur, res est plena difficultatum.

$5-684409$ Wikman 
out into the dark and crying at home. Someone who loses a person through violent death is petrified at nightfall and sees things which are non-existent. In former days spirits were considered godly things, and the credulous multitude create their own." 1 To this group of spirits Linnæus attributes lares and penates (the usual interpretation of the Swedish tomtar, vättar, hobgoblins and gnomes), mountain-trolls, fairies in the woods (named by Linnæus skogsnuvor), and water spirits (Swedish näckar), which, according to popular beliefs, could kidnap humans and cause their death. These supernatural beings are also listed under the heading: Idolatry, as Neptunus, Nymphæ, Najades, Dryades, Satyri and are apparently connected with classical mythology for no reason except that some of them behave in a demoniacally seducing and violating way. ${ }^{2}$ This feature holds good especially for the erotic dream-beings in nightmares (Ephialtes). With regard to the nightmare Linnæus draws attention to some obviously direct observations from the life of the people. He says: "The nightmare affects the farm-hands. It tries to assault and almost suffocate them. The remedy is to throw themselves to one side, whilst the nightmare falls to the floor." Linnæus presumes that the reason for such a "strange illness" (mirus morbus) could have been flatulency. ${ }^{3}$ Clearly he tries here as in many other instances, to explain popular misrepresentations in a rational way.

Linnæus has a similar explanation at hand when the question of the watersprite, the näck, is brought up. The water-sprite is seen as a naked man in the water, but as a brindled horse on land. He takes hold of the swimmer's leg, pulls him under the water, and then sucks blood out of him. The cause of this is given as cramp in cold water (spasmus ab aqua frigida). ${ }^{4}$

About the female wood nymph, skogsnuva, Linnæus tells us: "She misleads one in the woods. If one cannot find the way home and is bewildered, one

$1 L N-M S S$, fol. $16^{\mathbf{r}}$.

$2 L N-M S S$, fol. $16^{r}$ and $10^{r}$.

${ }^{3}$ In the original text $L N$-MSS $16^{\mathrm{v}}$ : Oritur a musto, cerevisia recenti et omnibus flatulentis.

${ }^{4} L N$-MSS, fol. I $6^{\mathrm{r}}$. The story is told from Småland as also the accompanying charm of "binding the Neck". Cf. Samuel Ödmann, Hägkomster, Örebro r 864, pp. 55 sq.; K. Rob. V. Wikman, Magiska bindebruk in the journal Hembygden, Helsingfors I9I2, pp. 67 sqq.; W. Liungman, Sveriges sägner, II, Örebro I958, pp. 26 sqq.; I32 sq. 
should turn one's jacket inside out, whereupon she goes away with a laugh." Seducit in sylvis homines et a via ducit. ${ }^{1}$

Undefined beings such as goblins (tomtar), and gnomes (vättar), in Roman interpretation penates and lares, are explained away as being figures of the imagination and sense-delusions. Linnæus is unreserved on this point: Rustici credunt quod tales dentur, adportant et exportant bona. Falsa omnino sunt hæc nec visa umquam quod credo. ${ }^{2}$

Concerning the prevalent folk-belief which maintained that gnomes and similar spirits could be heard hammering and chopping in a house which was under construction, even after the workmen had left, ${ }^{3}$ Linnæus suggests that the causes for such fancies were the deathwatch-beetle. ${ }^{4}$

Under the heading of Spectres Linnæus lastly lists some kind of ghostlights, probably St. Elmo's fires (ignis lambens), fetch-lights (ignis fatuus), and ghost-fires (Swedish gasteld). ${ }^{5} \mathrm{He}$ explains most of them as phenomena in the air.

About an ignis fatuus seen by himself and his brother-in-law he narrates the following peculiarity:

I726 vidi in lacu ubi submersæ anno præteriti duæ feminæ, ignem ac si candela lucisset supra undas, idque vero cum Pastore et marito sororis Höok.

However, at almost the same time, Linnæus and his teacher, Rothman, exposed another light as being the reflection of a stone bathed in moonlight. The doubt in the mind seems undeniable, otherwise Linnæus would never have reported this experience in Lachesis. ${ }^{6}$

By the conception spectres Linnæus refers to wicked spirits in popular beliefs, such as trolls, evil spirits, and the devil. According to the account of the Bible, he states, the mountain trolls are descended from Lucifer and his family. This is why the mountains raise themselves on four pillars on

${ }^{1} L N$-MSS, fol. $10^{\mathrm{r}}, 16^{\mathrm{r}}$. Cf. about skogsnuva G. O. Hyltén-Cavallius, op. cit., I, pp. 277 sqq.

${ }^{2} L N$-MSS, fol. $16^{\mathrm{r}}$.

${ }^{3}$ Ibidem. These views are obviously confused with tales about hobgoblins still hammering during the night when the workers on the building have gone home. Cf. G. O. Hyltén-Cavallius, op. cit., I, pp. 269 sq.

${ }^{4} L N$-MSS, fol. $\mathrm{I}^{\mathrm{v}}$.

5 LN-MSS, fol. I $7^{\mathrm{r}}$.

${ }^{B} L N$-MSS, fol. $16^{\mathrm{r}}$. 
Christmas Night. The Trolls kidnap people, who, if they do not eat or talk, are thrown out after three days. Such spirits exchange new-born babies; they take human children aud replace them with their own troll-children (fatui) who eat but do not talk. The people threaten to throw the young trolls into a hot oven and in this way cause the return of their own children. ${ }^{1}$ "For those who are possessed by the Devil and suffer from demonomania, which is an inflammatio cerebri" Linnæus recommends a medical doctor and not a priest. Witches (Swedish trollpackor), "who ride to Blåkulla anoint themselves, are intimate with the Devil, force their way into churches, journey on clouds etc., were in the old days condemend to burn eternally." However, those who in delirium, accused each other, confessed and spoke in fear "would, in our own day, hardly be condemned in this way by any judge", says Linnæus. "As a Christian I refuse to comment upon the existence of the Devil or devils", he declares, but adds: "To believe that the Devil is Almighty and that he can influence different bodies etc., is to credit him with the gifts which adhere to God. The wise man shall not deny that which is true, nor shall he believe that which is false. Ignorance about nature can cause much harm. This is why common people see and hear so much. How could this possibly remain unknown to the natural scientist: Ne credatis, nisi quod manus vestra occulta videre." ${ }_{2}$

On the I9th August, I74I, Linnæus and his companions visited the Court of Appeal at Jönköping in Northern Småland where they saw a large collection of witchery-instruments such as black-books, magic knots, a hornpipe which had been used to conjure forth spirits, and a rod which was used to milk another person's cow. Linnæus writes: "We blew on the magic hornpipe without devils appearing, and we also used the milking rod to no avail." 3 This amusing experiment is a token of the new era of the Enlightenment, when the belief in devils, witches and spells was becoming a thing of the past among educated people.

As a physician and naturalist Linnæus devoted himself mainly to the active expression of popular magic. We must bear in mind that, for him,

$1 L N-\mathrm{MSS}$, fol. $16^{\mathrm{V}}$.

${ }^{2} L N-M S S$, fol. $16^{\mathrm{V}}$ and $17^{\mathrm{V}}$.

3 Öländska och gothländska resa p. 330. 
superstitious fiction is only a long list of indications of psychic abnormalities. He mentions Nymphx, Najades and Dryades in connection with Idolatry, but presumably he has in mind the practices used by the country-people in order to placate supernatural powers in water-courses, lakes, holy wells and trees. Obviously these powers are not regarded as spectres. Only incidentally is the name of $\mathscr{f}$ upiter, the Old Northern Thor, mentioned in connection with the prevalent notions about the widely spread prohibitions of spinning on Thursday evenings. It is also said that needles and coins are thrown into a sacrifical well to cure itching. If someone takes them out the illness is transferred to him. If someone chops down a holy tree he becomes sick and may even die. If twigs or leaves are removed, the picker gets ill and is obliged to return them, etc. ${ }^{1}$

Linnæus' Dietetic concludes in a plea for psychic health and healing. His concept of animi pathemata is in no way meant as psychiatry. The attitudes of mind include such subjects as have been mentioned in this chapter. A methodically elaborated system is lacking. However, some distinctions are very important, as when Linnæus distinguishes magic from popular superstitions and also superstition from stories of ghosts, spooks and apparitions (spectra, manes). His magia is science, even if it is an occult science. Contrariwise superstitio is the irrational way of popular thinking and acting, owing to prejudices or shortcomings of experience and theory. The only cure for this is a rational knowledge of nature. The problem is how to gain this knowledge, and how to make it known amongst the people. This seems to us a very simple question, but for Linnæus it became a "respectable argument" for the understanding of the reasoning and actions of the common people. To this end it was necessary to bring together "a considerable collection" of material in order not only to show their origin but also prevent the flourishing practices of healers and quacks. For this purpose Linnæus appealed to his extensive clientel of students and especially to the young theologians among his audience, and his appeal was not without success.

${ }^{1}$ LN-MSS, fol. Io'. The supernatural beings of nature which are concerned are commonly expressed with Swedish vård, rå 'holding spirit'. Cf. The Supernatural Owners of Nature, ed. by Ake Hultkrantz (Stockholm Studies in Comparative Religion I), Stockholm 196I. 
These activities of Linnæus, who was then a young Professor of medicine at the University of Upsala, became generally known and had considerable influence. He had a fair harvest of memories from his youth in his native province to which he could add new items from his journeys. Superstitiosa tota gens Smolandix, he declares, and subsequently he chiefly enters this material in his lecture-notes. ${ }^{1}$ But such notes may also have crept in from other sources. As mentioned above, medicinal and fictional folklore is to be found in other parts of the Lachesis manuscript. On several occasions Linnæus remarks that a superstition may have a sympathetic origin. This seems to be an intricate question, because it clearly shows that the distinction between learned magic and popular superstition is a highly ambiguous matter. What then is the difference? Neither rational experience nor the tentative doctrine of sympathies was enough to disperse popular beliefs. Linnæus sensed that one had to delve further into man's psychical depths in order to be able to explain these phenomena.

As a general basis for popular beliefs Linnæus considered in the first instance a child's fright of the dark. His description of the emotional background is very personal. He emphasizes the fact that children are so afraid of the dark that they simply dare not venture outside. "Common sense does not help here. I never dared to go out alone before I was twenty, and even now I shudder in certain rooms, although I know better."2 Linnæus often returns to this subject and its importance for the educational system of his day. To understand him we must recollect, like the famous psychologist William James, that the ghostly terror is composed of several components, such as "loneliness, darkness, inexplicable sounds, especially of a dismal character, moving figures, half discerned (or if discernible, of dreadful aspect), and a vertiginous baffling of expectation." 3 Finally, according to James, the intellectual element enters into the context. With regard to Linnæus' own personal views we have to seek their background in a theme "filled with difficulties". The attempts at physical explanation in Linnæus' time served the purposes of the Enlightenment. Where the emotive attitudes of the mind were concerned, however, the shortcomings of such attempts

i $L N$-MSS.

${ }^{2} L N$, p. I 5 o.

${ }^{3}$ Principles of Psychology, I, I910, p. 419. 
were too apparent not to be discerned by Linnæus himself. The psychical basis of his reasoning, however, is discernible, though disguised by the actual wording.

In this connection a crucial point suggests itself in the concept hamn, which Linnæus renders with the Latin term manes. This concept refers not only to popular beliefs but also to Linnæus' own experiences. The popular beliefs concerning the destiny of man are closely connected with the old Scandinavian words: ham, hamingja and fylgja, the representations of which in the more modern Scandinavian languages are expressed by a great number of terms such as: Norwegian ham, Swedish hamn, Norwegian vard, vord; Swedish vaird (cf. Swedish varsel); Norwegian ferd (foreferd), Swedish färd; Norwegian fegda, Swedish fegd (the old Scandinavian adjective feigr has its counterpart in all Germanic languages). The general folkloristic meaning of hamn can, in English, be rendered with the Gaelic word wraith. ${ }^{1}$ However, the deep-lying interdependence of these concepts cannot be penetrated here. We can only refer to the recent account given by the prominent Norwegian folklorist Dr. Lily Aall, based on Norwegian materials. ${ }^{2}$

Psychologically these concepts have been debated very frequently. Dr. Aall has shown that not a single one of the existing general theories can be significantly applicable to this material. The reason for this is simply that any psychologically relevant theory miscarries. Only tentatively may we propose a description of these phenomena as psychic projections with a conspicuous tendency to dissociate and disintegrate, or, in accordance with one's personal structure and habits, to be conceived, even though vaguely, as activities or beings in the external world. Of course in this connection visual, auditive, and other sensory dispositions enter into the picture. The

1 John Brand, Popular Antiquities, London I888, pp. 705 sq.; concerning fylgia Jan de Vries, Altgermanische Religionsgeschichte, I, 2. Aufl., Berlin 1956, p. 228: "nicht nur eine Projektion des inneren Wesens eines Menschen nach aussen sondern auch ein ausserhalb des Menschen für sich bestehendes Wesen".

${ }^{2}$ Lily Weiser-Aall, En studie om vardøger, Norveg. Folkelivsgransking 12, Oslo 1965, pp. 73-1 12 (with a summary in German). 
72

border-line between the normal and the abnormal may be both uncertain and indefinite.

Linnæus' aim with his Dietetic was not to provide us with data for such conclusions. His arguments, however, would appear to be of some importance when here, and in what follows, our aim will be to try to obtain an overall picture of Linnæus' way of thinking and of his personality. 